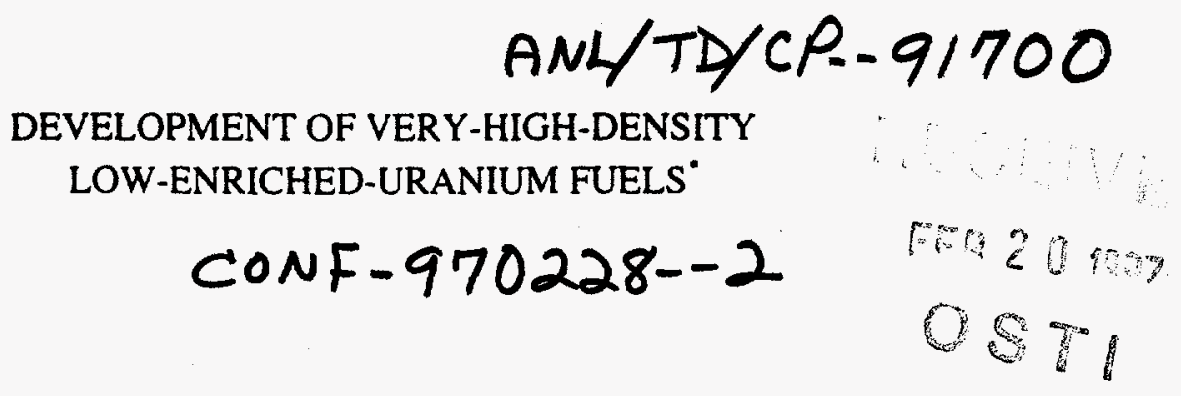

J. L. Snelgrove, G. L. Hofman, C. L. Trybus, and T. C. Wiencek

Argonne National Laboratory

Argonne, Illinois U.S.A.

James L. Snelgrove

Coordinator for Engineering Applications, RERTR Program

Argonne National Laboratory

9700 South Cass Avenue, Bldg. 207

Argonne, IL 60439-4841 U.S.A.

Phone: (630) 252-6369

Fax: (630) 252-5161

E-mail: jimsnelgrove@anl.gov

To Be Presented at the

1st International Topical Meeting on

Research Reactor Fuel Management (RRFM)

February 5-7, 1997

Bruges, Belgium
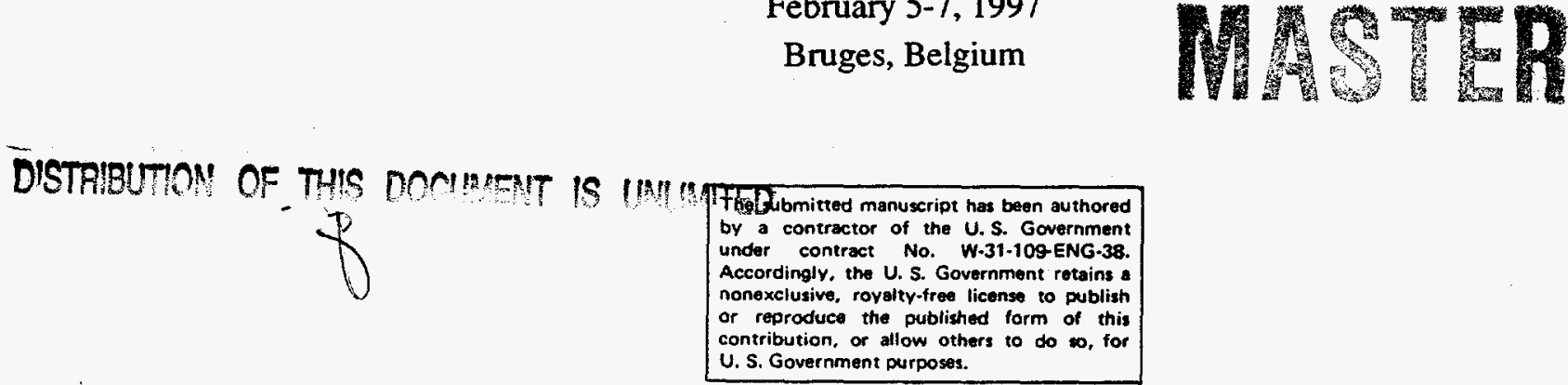

"Work supported by the U.S. Department of Energy,

Office of Nonproliferation and National Security, under Contract No. W-31-109-ENG-38 


\section{DISCLAIMER}

This report was prepared as an account of work sponsored by an agency of the United States Government. Neither the United States Government nor any agency thereof, nor any of their employees, make any warranty, express or implied, or assumes any legal liability or responsibility for the accuracy, completeness, or usefulness of any information, apparatus, product, or process disclosed, or represents that its use would not infringe privately owned rights. Reference herein to any specific commercial product, process, or service by trade name, trademark, manufacturer, or otherwise does not necessarily constitute or imply its endorsement, recommendation, or favoring by the United States Government or any agency thereof. The views and opinions of authors expressed herein do not necessarily state or reflect those of the United States Government or any agency thereof. 


\section{DISCLAIMER}

Portions of this document may be illegible in electronic image products. Images are produced from the best available original document. 


\title{
DEVELOPMENT OF VERY-HIGH-DENSITY LOW-ENRICHED-URANIUM FUELS
}

\author{
J. L. Snelgrove, G. L. Hotman, C. L. Trybus, T. C. Wiencek \\ Argonne National Laboratory \\ Argonne, Illinois U.S.A.
}

\section{INTRODUCTION}

Fuel development has been a cornerstone of the U.S. Reduced Enrichment for Research and Test Reactors (RERTR) program since its inception in 1978. This development work, performed cooperatively with many partners internationally, resulted by 1987 in the qualification of several dispersion fuels having significantly increased densities: $\mathrm{UAl}_{\mathrm{x}}-\mathrm{Al}$ at $2.3 \mathrm{~g} \mathrm{U} / \mathrm{cm}^{3}, \mathrm{U}_{3} \mathrm{O}_{8}-\mathrm{Al}$ at $3.2 \mathrm{~g} \mathrm{U} / \mathrm{cm}^{3}$, and $\mathrm{U}_{3} \mathrm{Si}_{2}-\mathrm{Al}$ at $4.8 \mathrm{~g} \mathrm{U} / \mathrm{cm}^{3}$. Approximately 20 reactors have been converted from high-enriched uranium (HEU) to low-enriched uranium (LEU), and several new LEU reactors have been built using these fuels. In most cases the uranium silicide fuel has been used.

Although a fuel with a uranium density of $4.8 \mathrm{~g} \mathrm{U} / \mathrm{cm}^{3}$ is sufficient to convert approximately $90 \%$ of the research reactors outside the U.S. which used HEU of U.S. origin in 1978, conversion of the remaining reactors, which use a significant quantity of $\mathrm{HEU}$, require fuels having considerably higher densities. Therefore, the RERTR program continued to develop methods to fabricate plates containing higher loadings of uranium silicide fuels until funding constraints forced an end to this work at the end of September 1989. CERCA, one of the RERTR program's key partners in the development of uranium silicide dispersion fuel, continued its development efforts and announced in 1993 that it had developed an advanced fabrication process which allowed the loading of $\mathrm{U}_{3} \mathrm{Si}_{2}-\mathrm{Al}$ fuel to be increased to $6.0 \mathrm{~g} \mathrm{U} / \mathrm{cm}^{3}[1]$.

Even though development of higher-density fuels was stopped, analysis of the irradiation experiments performed earlier in the RERTR program continued, resulting in a better understanding of the fundamental behavior of these fuels. Also, work continued to better understand and refine dispersion fuel fabrication techniques. Papers reporting these results have been presented annually at the RERTR international meetings. During this period of decreased fuel development activity within the RERTR program, development of uranium silicide dispersion fuel in the U.S. continued under the auspices of Oak Ridge National Laboratory's (ORNL's) Advanced Neutron Source (ANS) project, with Argonne National Laboratory (ANL) designated as the lead fuel development laboratory [2]. A series of three irradiation experiments in the High Flux Isotope Reactor (HFIR) at ORNL provided data on fuel behavior at high temperatures and high fission rates, and revealed that there are limits to the use of $\mathrm{U}_{3} \mathrm{Si}_{2}-\mathrm{Al}$ under these conditions. Results from the most recent of these experiments prompted a major new analysis of $\mathrm{U}_{3} \mathrm{Si}_{2}-\mathrm{Al}$ fuel irradiation behavior [3]. Irradiation performance modeling was also emphasized since fuels could not be tested at or beyond ANS conditions. The advances made during this interim period have helped provide a good basis for further development of dispersion fuels.

In 1994 the Department of Energy announced its intention to resume the development of veryhigh-density fuels to address needs of existing and new research and test reactors. However, owing to pressures of a shrinking federal budget, funding for this work could not be made available until last March. This paper describes the plans and schedule of this new development work.

\section{GOAL AND APPROACH}

We have set a goal of achieving a uranium density in a dispersion fuel meat of 8 to $9 \mathrm{~g} \mathrm{U} / \mathrm{cm}^{3}$. We think that such a density is achievable from the fabrication point of view, and it matches the 
RERTR program's assessments of uranium densities needed to convert the reactors not convertible using $4.8 \mathrm{~g} \mathrm{U} / \mathrm{cm}^{3} \mathrm{U}_{3} \mathrm{Si}_{2}$ fuel. Of course, irradiation behavior and fabrication costs will ultimately determine the success of any proposed fuel.

We think that the best chance of successfully developing a fuel with acceptable fabrication cost lies with extension of the current aluminum-based dispersion fuel concept. Since CERCA's experience with highly loaded $\mathrm{U}_{3} \mathrm{Si}_{2}-\mathrm{Al}$ [1] and UN-Al [4] fuels indicates that one is not likely to achieve a fuel volume loading greater than $55 \%$ in a commercially viable process, fuel dispersants with very-high uranium densities, $\geq 15 \mathrm{~g} \mathrm{U} / \mathrm{cm}^{3}$, must be used. With the exception of $U_{6} \mathrm{Fe}$ and $\mathrm{U}_{6} \mathrm{Mn}$, which were tested earlier in the RERTR program and shown to be subject to breakaway swelling at relatively low burnups $[5,6]$, and the similar compounds $U_{6} C_{0}$ and $U_{6} N i$, which are also expected to exhibit poor swelling behavior, no uranium compound meets our density requirement.

Therefore, only pure uranium metal or alloys of uranium and small amounts of other metals can be considered as fuel dispersants. Although pure uranium is a notoriously poor performer under irradiation, a series of alloys which maintain uranium in the metastable $\gamma$ phase have shown good irradiation performance in bulk form under fast reactor conditions. Examples of such alloys are listed in Table 1.

Table 1. Densities of Representative $\boldsymbol{\gamma}$-Phase Uranium Alloys

\begin{tabular}{|c|c|c|}
\hline Alloy* & Density, $\mathrm{g} / \mathrm{cm}^{3}$ & $\mathrm{U}$ Density, $\mathrm{g} / \mathrm{cm}^{3}$ \\
\hline $\mathrm{U}-9 \mathrm{Mo}$ & 17.0 & 15.5 \\
\hline $\mathrm{U}-5 \mathrm{Mo}$ & 17.9 & 17.0 \\
\hline $\mathrm{U}-3 \mathrm{Zr}-9 \mathrm{Nb}$ & 16.2 & 14.3 \\
\hline $\mathrm{U}-4 \mathrm{Zr}-2 \mathrm{Nb}$ & 17.3 & 16.3 \\
\hline
\end{tabular}

*Alloying element amount given in wt.\%.

Our experience with the $\mathrm{U}_{3} \mathrm{Si}_{2}$ - $\mathrm{Al}$ dispersion fuel taught us that the key issues which must be addressed are the reaction of the fuel alloys with the matrix and the irradiation behavior of the fuel alloys and of any reaction products. Should reaction of the fuel alloys with an aluminum matrix be excessive, we will investigate the use of a magnesium matrix while retaining the aluminum cladding, since magnesium does not form compounds with uranium. We have also considered using zirconium as both matrix and cladding material, but we do not currently plan to pursue this option owing to concerns about fabrication cost.

\section{PLANS AND SCHEDULE}

\section{Fabrication}

During the early stages of the RERTR program, fabrication development was performed at ANL's Illinois site (ANL-East), at Oak Ridge National Laboratory (ORNL), and at the Idaho National Engineering Laboratory (INEL). However, by early 1996 only a very small development group at ANL-East remained. Therefore, a major increase in our fabrication development capacity was required to support an aggressive fuel development effort. In order to utilize best the resources available within ANL, we decided to augment the fabrication development group at ANL-East and to establish a new fabrication development laboratory and group at ANL's Idaho site (ANL-West). The procurement process for most of the equipment needed at ANL-West is underway, and detailed installation plans are being prepared. In addition, we have reached the currently required staffing levels at both sites. At ANL-West we have already begun to produce fuel alloys and expect to begin 
producing fuel powder, by mechanical means, and compacts for small test plates by the end of November 1996. We anticipate that the development laboratory will be ready for full use before the end of CY 1997, when the installation of the longest-lead item, the rolling mill, will have been completed. In the meantime, we will carry out all rolling operations at ANL-East. In particular, the first rolling experiments have already been performed and fuel plates for the initial irradiation tests (discussed below) are scheduled to be rolled during the first quarter of CY 1997.

We plan to follow the development pattern that worked so successfully for the uranium silicide fuel, that is, to limit our fabrication development to the study of basic issues and to the production of small fuel plates for irradiation testing and to depend on the commercial fabricators to adapt and extend our results to the fabrication of full-sized fuel plates or tubes. We have held preliminary discussions with both Babcock and Wilcox (B\&W) and CERCA. Both are interested in participating but will need to assess further the commercial potential of the proposed fuels before deciding the amounts of company resources which can be committed to the required development work.

ANL and the Korea Atomic Energy Research Institute (KAERI) are setting up a cooperation agreement under which the use of atomized fuels will be explored. KAERI recently completed a study of fuel-matrix reaction rates in dispersions of U-Mo alloys in aluminum, with encouraging results [7]. KAERI has agreed to provide a small quantity of U-Mo powder for fabrication development work at ANL.

\section{Materials Properties Studies}

In order to address the key issues stated above, a number of studies are planned on the phase structure of the uranium alloys and diffusion of the matrix materials into the alloys. We expect to make substantial progress in this work over the next year. ANL is also negotiating a cooperation agreement with the A. A. Bochvar All-Russian Research and Development Institute of Inorganic Materials in Moscow, under which phase studies of interacting materials is one area of possible collaboration.

\section{Irradiation Behavior Experiments}

Little is known about the irradiation behavior of the proposed fuel alloys when they are dispersed in aluminum or about the behavior of the fuel itself at the high burnups typical of research and test reactors. Our highest priority is to begin irradiation screening tests of the proposed dispersions. We are planning to perform these irradiations in the Advanced Test Reactor (ATR) at INEL and to perform the postirradiation examinations at ANL-West. All of the preparatory activities required for the irradiations are underway, including design of the experiment rig, safety analysis of the experiment, and coordination with the ATR experiment staff.

Because of space limitations in irradiation holes near the core, the fuel plates (which we are calling microplates) must be much smaller than the miniplates irradiated previously by the RERTR program in the Oak Ridge Research Reactor (ORR). The current design calls for microplates with outside dimensions $76 \mathrm{~mm} \times 22 \mathrm{~mm} \times 1.3 \mathrm{~mm}$, compared to the $114 \mathrm{~mm} \times 51 \mathrm{~mm} \times 1.3 \mathrm{~mm}$ dimensions of a typical ORR miniplate. The microplates will be produced using 9.5 - $\mathrm{mm}$-diameter cylindrical compacts, resulting in an elliptical-shaped fuel zone with nominal dimensions of $57 \mathrm{~mm} \mathrm{x}$ $9.5 \mathrm{~mm} \times 0.5 \mathrm{~mm}$ and an area of $<500 \mathrm{~mm}^{2}$, whereas the rectangular fuel zone of the typical miniplate measured $102 \mathrm{~mm} \times 46 \mathrm{~mm} \times 0.5 \mathrm{~mm}$ and had an area of $4692 \mathrm{~mm}^{2}$. Nevertheless, mechanical analyses have shown that the fuel zone area of the microplate is large enough to behave in the same manner as that of a much-larger plate.

Since the first tests will focus on fuel particle-matrix interactions and fuel particle swelling, it is not necessary to test plates with uranium densities approaching the 8 to $9 \mathrm{~g} \mathrm{U} / \mathrm{cm}^{3} \mathrm{goal}$. In fact, it is much more important to obtain results as quickly as possible. Therefore, in order to minimize heat removal problems in the design of the irradiation rig and to minimize fuel plate fabrication problems, we will limit the uranium density to no more than $4.8 \mathrm{~g} \mathrm{U} / \mathrm{cm}^{3}$. 
$U_{3} \mathbf{S i}_{2}-\mathbf{A l}$

Because $\mathrm{U}_{3} \mathrm{Si}_{2}-\mathrm{Al}$ fuel is being used in many research and test reactors today and is being chosen as fuel for new reactors being designed, the RERTR program remains committed to provide support for current and potential users of this fuel. Our current emphasis is on obtaining a better understanding of the limits to the applicability of $\mathrm{U}_{3} \mathrm{Si}_{2}-\mathrm{Al}$ fuel in certain high-temperature, highfission rate situations [3]. More data are needed to further define those limits. The French CEA is currently irradiating some 5.8 and $6.0 \mathrm{~g} \mathrm{U} / \mathrm{cm}^{3}$ plates in SILOE, and we have been discussing a collaboration with the CEA in performing postirradiation examinations of these plates. In addition, we are considering the possibility of performing another irradiation in the HFIR.

The ANL-KAERI cooperation agreement also calls for the irradiation in HANARO of miniplates fabricated in the U.S., some containing atomized $\mathrm{U}_{3} \mathrm{Si}_{2}$ powder produced by KAERI and some containing the traditional comminuted $\mathrm{U}_{3} \mathrm{Si}_{2}$ powder in order to demonstrate the acceptable irradiation characteristics of the atomized fuel. A miniplate irradiation rig for HANARO is currently being designed, and preliminary thermal-hydraulic safety calculations for the experiment have been completed.

$\mathrm{UO}_{2}$

Considerable experience in the behavior of $\mathrm{U}_{3} \mathrm{O}_{8}$ - $\mathrm{Al}$ dispersion fuel was obtained during the early phases of the RERTR program. Our interest in $\mathrm{UO}_{2}-\mathrm{Al}$ fuel has been kindled by our collaboration with the Russian RERTR program, in which that fuel is being tested up to $3.8 \mathrm{~g} \mathrm{U} / \mathrm{cm}^{3}$ for use in converting certain Russian-designed research reactors to use LEU. We have revised the DART code to include a model for uranium oxide, based on the $\mathrm{U}_{3} \mathrm{O}_{8}$ data [10]. We expect to continue to work with our Russian colleagues to evaluate the results of irradiation tests planned to begin within the next year.

\section{UN}

In 1994, CERCA reported that uranium densities of about $7.0 \mathrm{~g} \mathrm{U} / \mathrm{cm}^{3}$ could be achieved in UNAl dispersion fuel by a commercially acceptable process [4]. Although this achievement represented a significant advance in uranium density, a study performed at ANL [11] has shown that the ratherlarge thermal neutron absorption cross section of nitrogen substantially reduces the advantage of UN$\mathrm{Al}$ fuel over $\mathrm{U}_{3} \mathrm{Si}_{2}-\mathrm{Al}$ fuel at the same fuel volume loading. We understand, however, that concerns about problems presented by uranium silicide fuels in the back end of the fuel cycle have prompted some consideration of the use of $\mathrm{UN}$ as a substitute for $\mathrm{U}_{3} \mathrm{Si}_{2}$. We have found only one reference to irradiation of UN-Al fuel [12]. The swelling of UN-Al fuel at about 14 vol.\% loading was found to be greater than that of $\mathrm{U}_{3} \mathrm{O}_{8}-\mathrm{Al}$ fuel at a similar volume loading. Irradiation behavior data at high loadings of $\mathrm{UN}$ are not available; however, based on the low-loading data and our evaluation of $\mathrm{U}_{3} \mathrm{O}_{8}-\mathrm{Al}$ swelling [10], we think that severe burnup limits will be required for high-density UN-Al fuel. Nevertheless, the RERTR program will be happy to collaborate in evaluating the usefulness of this fuel as an alternative to $\mathrm{U}_{3} \mathrm{Si}_{2}$.

\section{CONCLUSIONS}

The RERTR program has recently begun an aggressive effort to develop dispersion fuels for research and test reactors with uranium densities of 8 to $9 \mathrm{~g} \mathrm{U} / \mathrm{cm}^{3}$, based on the use of $\gamma$-stabilized uranium alloys. Fabrication development teams and facilities are being put into place, and preparations for the first irradiation test are in progress. The first screening irradiations are expected to begin in late April 1997 and the first results should be available by the end of 1997. Discussions with potential international partners in fabrication development and irradiation testing have begun. 


\section{REFERENCES}

1. J. P. Durand and Y. Fanjas, "LEU Fuel Development at CERCA: Status as of October 1993," Proc. 16th International Meeting on Reduced Enrichment for Research and Test Reactors, October 4-7, 1993, Oarai, Japan, JAERI-M 94-02, pp. 71-78, March 1994.

2. G. L. Copeland, "Fuel Qualification Plan for the ANS Reactor," ORNL/M-4324, July 1995.

3. G. L. Hofman, J. Rest, J. L. Snelgrove, T. Wiencek, and S. Koster van Groos, "Aluminum$\mathrm{U}_{3} \mathrm{Si}_{2}$ Interdiffusion and Its Implication for the Performance of Highly Loaded Fuel Operating at Higher Temperatures and Fission Rates," paper presented at the 19th International Meeting on Reduced Enrichment for Research and Test Reactors, October 6-10, 1996, Seoul, Korea.

4. J. P. Durand, P. Laudamy, and K. Richter, "Preliminary Developments on MTR Plates with Uranium Nitride," Proc. 1994 International Meeting on Reduced Enrichment for Research and Test Reactors, September 18-23, 1994, Williamsburg, Virginia, ANL/RERTR/TM-20, in press.

5. G. L. Hofman, R. F. Domagala, and G. L. Copeland, "Irradiation Behavior of Low-Enriched $\mathrm{U}_{6} \mathrm{Fe}-\mathrm{Al}$ Dispersion Fuel Elements," J. Nucl. Mater. 150, 238-243, 1987.

6. G. L. Hofman and L. A. Neimark, "Prospects for Stable High-Density Dispersion Fuels," Proc. $X$ International Meeting on Reduced Enrichment for Research and Test Reactors, Buenos Aires, Argentina, September 28 - October 1, 1987.

7. K. H. Kim, D. B. Lee, C. K. Kim, and I. H. Kuk, "Development of High Loading U-Mo Alloy Fuel by Centrifugal Atomization," paper presented at the 19th International Meeting on Reduced Enrichment for Research and Test Reactors, October 6-10, 1996, Seoul, Korea.

8. R. C. Birtcher, J. W. Richardson, and M. H. Mueller, "Amorphization of $\mathrm{U}_{3} \mathrm{Si}_{2}$ by Ion or Neutron Irradiation," J. Nucl. Mater. 230, 158-163, 1996.

9. J. Rest, "The DART Dispersion Analysis Tool: A Mechanistic Model for Predicting FissionProduct-Induced Swelling of Aluminum Dispersion Fuels," ANL-95/36, August 1995.

10. G. L. Hofman, J. Rest, and J. L. Snelgrove, "Irradiation Behavior of Uranium Oxide-Aluminum Dispersion Fuel," paper presented at the 19th International Meeting on Reduced Enrichment for Research and Test Reactors, October 6-10, 1996, Seoul, Korea.

11. M. M. Bretscher, J. E. Matos; and J. L. Snelgrove, "Relative Neutronic Performance of Proposed High-Density Dispersion Fuels in Water-Moderated and $\mathrm{D}_{2} \mathrm{O}$-Reflected Research Reactors," paper presented at the 19th International Meeting on Reduced Enrichment for Research and Test Reactors, October 6-10, 1996, Seoul, Korea.

12. M. J. Graber, W. F. Zelezny, and R. A. Moen in Annual Progress Report on Reactor Fuels and Materials Development for FY 1965, W. C. Francis, Ed., IDO-17154, p. 11, February 1966. 